\title{
Diurnal Variations of $\delta 180$ and its Quantitative Differentiation in Evapotranspiration Components of main Larix Gmelinii Forest types in Cold Temperate Zone
}

\section{Xin Zhang}

Inner Mongolia Agricultural University https://orcid.org/0000-0001-5634-2921

Qiuliang Zhang ( 18686028468@163.com )

Inner Mongolia Agricultural University

\section{Rui Wang}

Inner Mongolia Agricultural University

Yanan Jian

Inner Mongolia Agricultural University

Jingfu Yang

Inner Mongolia Agricultural University

Changlei Sun

Inner Mongolia Agricultural University

Jiafu Wang

Inner Mongolia Agriculture University

\section{Research}

Keywords: Larix gmelinii, Different forest types, Oxygen isotope, Soil evaporation, Plant transpiration, Ecosystem evapotranspiration, Component quantitative differentiation

Posted Date: December 30th, 2020

DOl: https://doi.org/10.21203/rs.3.rs-135009/v1

License: (9) This work is licensed under a Creative Commons Attribution 4.0 International License. Read Full License 


\title{
Diurnal variations of $\delta^{18} O$ and its quantitative differentiation in evapotranspiration components of main Larix gmelinii forest types in cold temperate zone
}

\author{
Xin Zhang ${ }^{1}$, Qiuliang Zhang ${ }^{1,2 *}$, Rui Wang ${ }^{1}$, Yanan Jian ${ }^{1}$, Jingfu Yang ${ }^{1}$, Changlei Sun ${ }^{2}$ and Jiafu Wang ${ }^{3}$ \\ * Correspondence: $18686028468 @ 163 . c o m$ \\ ${ }^{1}$ Forestry College, Inner Mongolia Agriculture University, Hohhot 010019, China \\ 'Inner Mongolia Daxing' anling Forest Ecosystem National Field Science Observatory, Genhe 022350, China \\ Full list of author information is available at the end of the article
}

\begin{abstract}
Background: Evapotranspiration (ET) is an important process of ecosystem water cycle, including soil evaporation (E) and plant transpiration (T). Distinguishing the two parts is helpful to understand the water vapor exchange process and the contribution of $\mathrm{E} / \mathrm{T}$ to $\mathrm{ET}$ in the water dissipation structure of Soil-Plant-Atmosphere Continuum (SPAC). Larix gmelinii is the main constructive species of forest ecosystem in cold temperate zone, the diurnal variation of oxygen isotope composition $\left(\delta^{18} O\right)$ and its quantitative differentiation in ET components in main Larix gmelinii forest types were studied. It can provide scientific basis for regional water resources protection and forest ecosystem management.
\end{abstract}

Methods: The Off-Axis Integrated Cavity Output Spectroscopy (OA-ICOS) was used to measure the water vapor concentration and its $\delta^{18} O$ in 6 vertical gradients of the Larix gmelinii ecosystem. During the vigorous growth period of plants (June to July), plant branches and soil samples of 5 main forest types in the ecosystem were collected on typical sunny days. The $\delta^{18} \mathrm{O}$ values of the samples were determined by condensation vacuum extraction and liquid water isotope analyzer. Then, the Craig-Gordon model was used to estimate the $\delta^{18} O$ of E, the $\delta^{18} O$ of T is estimated based on the Isotopic Steady State (ISS) assumption, the $\delta^{18} O$ of ET was estimated by Keeling plot equation. Finally, the binary linear mixed model was used to estimate the contribution rate of ET component.

Results: The results showed that: (1) the variation trend of water vapor concentration and its $\delta^{18} O$ in different 
vertical gradients of Larix gmelinii ecosystem showed a "V" diurnal variation trend, with the minimum values appeared between 11:00 and 17:00, and the $\delta^{18} O$ decreased with the increase of height. The $\delta^{18} O$ of ET showed a "inverted V" diurnal variation trend, with the maximum values between 10:00 and 14:00, which was opposite to the variation trend of the ecosystem water vapor $\delta^{18} O$; (2) the $\delta^{18} \mathrm{O}$ of $\mathrm{E}$ in different forest types increased in daily scale, ranging from $-35.71 \%$ to $-29.12 \%$, which was smaller than the $\delta^{18} \mathrm{O}$ of soil surface water. The $\delta^{18} \mathrm{O}$ of $\mathrm{T}$ in different forest types decreased in a daily scale, ranging from $-14.22 \%$ to $-11.21 \%$, which was smaller than the $\delta^{18} O$ of plant water; (3) the contribution of T to ET was the largest from 10:00 to 14:00, with an average of $79 \%-96 \%$. The order of $\mathrm{T}$ contribution rate for each forest type from large to small was BL $(75.49 \pm 2.06 \%)$, RL (74.72 $\pm 2.12 \%), \operatorname{PL}(72.62 \pm 2.01 \%), \operatorname{SL}(72.42 \pm 2.78 \%)$ and LL $(72.35 \pm 1.99 \%)$. The contribution rate of $\mathrm{E}$ was the highest from 06:00 to 10:00, with an average of $28-47 \%$.

Conclusions: In the vigorous growth period of the Larix gmelinii ecosystem, the diurnal variation of $\delta^{18} O$ and its quantitative differentiation in ET components of different forest types were significant. T was the main source of the ET, on the whole, the contribution rate of $\mathrm{T}$ in shrub dominated Larix gmelinii forest was higher than that in grass dominated forest type, and moss dominated forest type.

Keywords: Larix gmelinii, Different forest types, Oxygen isotope, Soil evaporation, Plant transpiration, Ecosystem evapotranspiration, Component quantitative differentiation

\section{Background}

The water cycle of terrestrial ecosystem is an important ecological process of material cycle and energy exchange in terrestrial-atmosphere system (Yu et al. 2004), about 20\% of the water in the atmosphere is obtained from land evapotranspiration every year (Friend et al. 1997). Ecosystem evapotranspiration (ET) is the sum of soil evaporation (E) and plant transpiration (T) (Yuan et al. 2010). Atmospheric precipitation infiltrates into forest soil, soil surface water is lost to the air through soil evaporation, and deep soil water is lost to the air through plant root absorption, stem movement and leaf transpiration. water vapor in the air condenses to form precipitation, which is supplied to soil and plants again, forming a complete Soil-Plant-Atmosphere Continuum (SPAC) water vapor exchange process (Xu et al. 2017). Therefore, under natural conditions, the quantitative distinction between $\mathrm{E}$ and $\mathrm{T}$ is helpful to better understand the water vapor exchange process and the contribution of E/T to ET in the water dissipation structure of SPAC (Sun et al. 2005).

Stable isotopes of hydrogen and oxygen in water with natural abundance can well characterize the water vapor exchange process of SPAC (Gat et al. 1996), especially the development of Off-Axis Integrated Cavity Output 
Spectroscopy (OA-ICOS) technology, which solved the key problems of low sampling time resolution relying on cold trap technology in the past, and the large test results caused by the enrichment of identical elements during the sample cooling process (Wen et al. 2008). OA-ICOS realizes high time resolution observation of atmospheric water vapor isotope, which is suitable for continuous field observation and large sample analysis. The obtained data have high accuracy (Wen et al. 2008), and can be applied to a wider space and time scale. On the scale of ecosystem, the flow direction of $\mathrm{E}$ and $\mathrm{T}$ can be distinguished (Yepez et al. 2003), and on the time scale, the water dissipation status of the system can be reflected (Francey et al. 1987), which has become an important method for the study of ET components (Lin et al. 2003). In the study of ET quantitative differentiation of ecosystem, it is assumed that the oxygen isotopic composition of plant transpiration water vapor is consistent with that of branch water under the condition of "Isotopic Stable State (ISS)"(Wen et al. 2008). However, under the field conditions, the water isotope in plants is always in "Non Stable State (NSS)". The ISS hypothesis is only applicable to noon with strong transpiration or long time scale (several days or weeks) (Brooks et al. 2010). Therefore, the ET study based on ISS hypothesis mostly chooses the typical sunny days during the plant growing season with strong solar radiation, high air temperature and relatively low air, so as to minimize the impact of NSS [Zhang et al. 2010; Wang et al. 2013]. At present, researches on quantitative differentiation of ET were mainly focused on grassland ecosystem [Yepez et al. 2003; Good et al. 2012] and farmland ecosystem [Brunel et al. 1992; Yuan et al. 2010]. As the main component of terrestrial ecosystem, forest ecosystem plays an irreplaceable role in material circulation and energy exchange with soil, vegetation and atmosphere at multiple levels, scales and interfaces (Shi 2010). Due to many factors, such as tall trees, strong spatial heterogeneity, complex structure, and difficulties in field positioning and observation, ET quantitative differentiation of forest ecosystem is rarely reported (Zheng et al. 2009). There are few reports on quantitative differentiation of ET components based on a single forest type in a certain region [Sun et al. 2015; Liu et al. 2017]. However, in the same forest ecosystem in the same region, due to the differences of undergrowth vegetation, different forest types are formed, and their productivity and ET water consumption are different [Luo 1990; Wang et al. 2020].

Greater Khingan Range forest region is an important ecological barrier and timber strategic reserve base in northern China. The cold and humid environment of high latitude permafrost and wetland (swamp) has formed a unique Larix gmelinii ecosystem with complex forest types in cold temperate zone [Luo 1990; Wang et al. 2020]. Under the pattern of global climate change, permafrost melting, wetland shrinkage and warming and drying aggravate the degradation of Larix gmelinii ecosystem and the northward migration of distribution boundary [Zhang 1993; Jiang et al. 2001; Li et al. 2006; Leng et al. 2008]. Therefore, the study of water vapor isotopic composition $\left(\delta^{18} \mathrm{O}\right)$ and its quantitative differentiation of ET components of main Larix gmelinii forest types is 
helpful to improve the sustainable utilization of regional water resources and ecosystem protection. This study is based on stable isotope technique, continuous high - frequency observations of water vapor concentration and $\delta^{18} \mathrm{O}$ in different vertical gradients of the ecosystem were carried out. During the vigorous growth period of of Larix gmelinii ecosystem (June to July), plant branches and soil samples of 5 main forest types in the ecosystem were collected on typical sunny days. The $\delta^{18} O$ values of the samples were determined by condensation vacuum extraction and liquid water isotope analyzer. The main purpose of the study are: (1) to analyze the difference of $\delta^{18} \mathrm{O}$ in water vapor of different vertical gradients in Larix gmelinii ecosystem; (2) to estimate the $\delta^{18} \mathrm{O}$ of $\mathrm{E}$ and T in different Larix gmelinii forest types; (3) to quantify the contribution rate of E/T to ET in different forest types, so as to provide a basis for further study of water vapor exchange and the sustainable management of Larix gmelinii ecosystem in cold temperate zone.

\section{Methods}

\section{Study area}

The study was conducted from June to July 2020 at Inner Mongolia Daxing' anling Forest Ecosystem National Field Science Observatory $\left(50^{\circ} 49^{\prime}-50^{\circ} 51^{\prime} \mathrm{N}, 121^{\circ} 30^{\prime}-121^{\circ} 31^{\prime} \mathrm{E}\right)$ in northeastern part of China (Fig. 1), the experimental area of the station is $11000 \mathrm{hm}^{2}$, with an average altitude of $976.5 \mathrm{~m}$, belonging to the humid monsoon climate zone of cold temperate zone. The annual average temperature is $-5.4^{\circ} \mathrm{C}$, the annual sunshine duration is $2630.7 \mathrm{~h}$, and the annual average precipitation is $350 \mathrm{~mm}-550 \mathrm{~mm}, 60 \%$ of which are concentrated in July and August, the snowfall period is from the end of September to the beginning of May of the next year, the snowfall thickness is $20 \mathrm{~cm}-40 \mathrm{~cm}$, and the snowfall accounts for $12 \%$ of the annual precipitation. The annual surface evaporation is $800 \mathrm{~mm}-1200 \mathrm{~mm}$, the frost free period is $80 \mathrm{~d}-90 \mathrm{~d}$, and the annual average wind speed is $1.9 \mathrm{~m} / \mathrm{s}$. The soil is dominated by brown coniferous forest soil, with a thickness of $40 \mathrm{~cm}-60 \mathrm{~cm}$, continuous permafrost and island permafrost are alternately distributed in the territory[Li et al. 2015; Tian et al. 2019].

Both the observation area and the sampling area are arranged in the comprehensive experimental area of the original Larix gmelinii forest in the ecological station. The forest coverage rate within $1 \mathrm{~km}^{2}$ around the observation area is about $92 \%$, with more than $90 \%$ of Larix gmelinii, and the rest are Betula platyphylla and Populus davidiana. There are five forest types in the experimental area, Rhododendron dauricum-Larix gmelinii forest (RL) mainly distributed below 1000m above sea level; Ledum palustre - Larix gmelinii forest (LL) mainly distributed in the lower part of the gentle slope; Pyrola incarnata-Larix gmelinii forest (PL) mainly distributed on gentle slopes and on the posts; Betula fruticosa-Larix gmelinii forest (BL) mainly located in the forest edge and valley, and Sphagnum palustre - Larix gmelinii forest (SL) mainly at the river beach. 


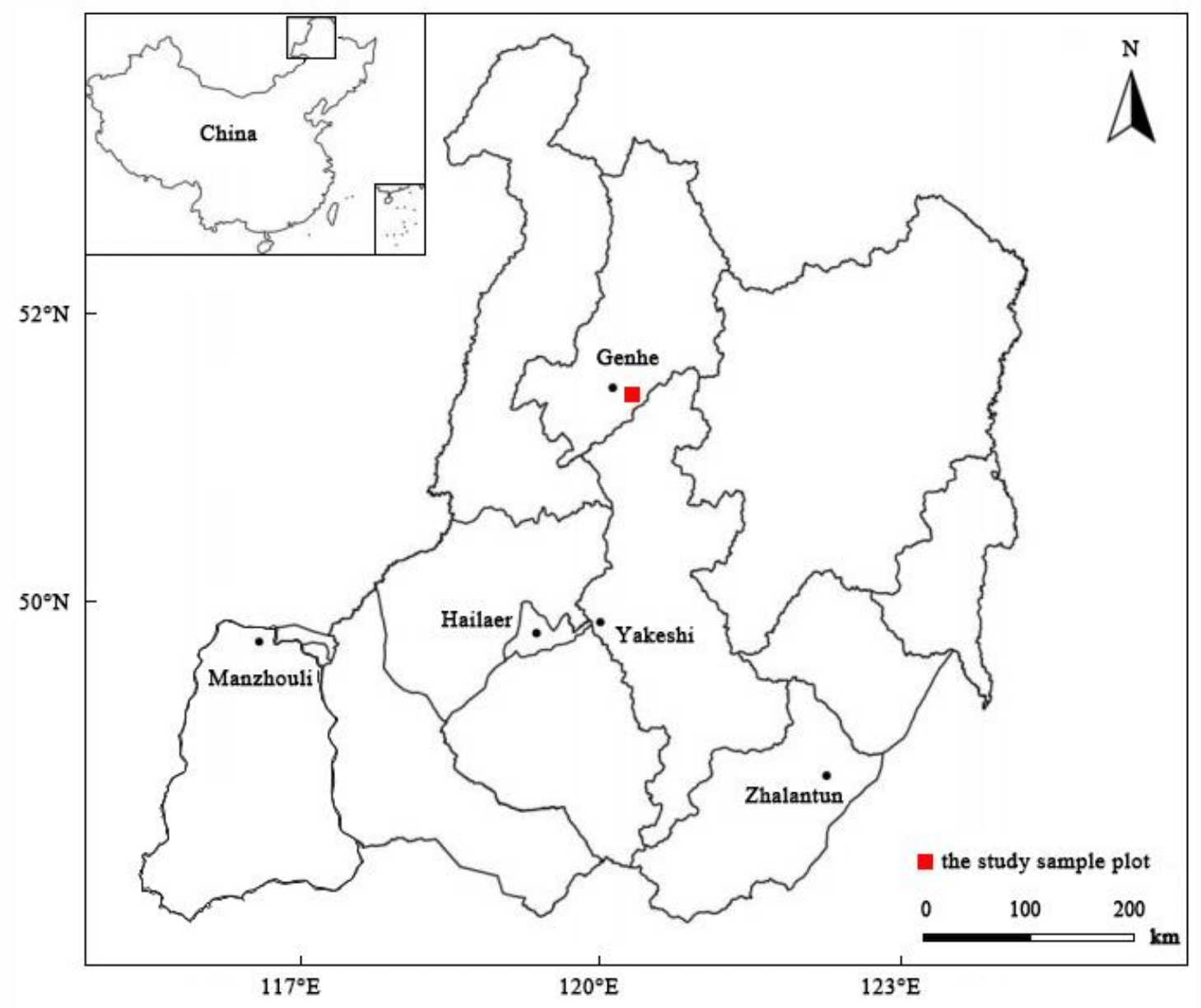

Fig. 1 Location of the study area.

\section{Observation and sampling methods}

\section{Observation of water vapor isotopes in different vertical gradients of ecosystems}

Using the Water Vapor Stable Isotope Profile Measurement System (WVIA, Los Gatos research Inc., USA), we conducted long - term continuous in - situ observation of water vapor concentration and isotopic composition $\left({ }^{18} \mathrm{O} /{ }^{16} \mathrm{O}\right)$ in Larix gmelinii ecosystem: near surface layer $(0.1 \mathrm{~m})$, upper shrub $(2 \mathrm{~m})$, lower canopy $(10 \mathrm{~m})$, middle canopy (16 m), upper canopy $(22 \mathrm{~m})$ and background atmosphere $(40 \mathrm{~m})$. The system is based on OA-ICOS technology, the measurement accuracy of ${ }^{18} \mathrm{O} /{ }^{16} \mathrm{O}$ is $0.15 \%$, the water vapor stable isotope measurement system is linked to the sampling point of each gradient with a $1 / 4$ inch outer diameter Teflon tube, The vacuum pump is used to pump the air, and a 16 channel multiplexer (Los Gatos research Inc., USA) controls the gas sampling time of different gradients, the sampling time of each gradient is $5 \mathrm{~min}$, in order to eliminate the influence of the last determination of residual gas in the intake pipe, the pipeline cleaning time of $0.5 \mathrm{~min}, 0.5 \mathrm{~min}, 1 \mathrm{~min}, 1 \mathrm{~min}, 1.5$ min and 2 min was set in the gradient conversion of $0.1 \mathrm{~m}, 2 \mathrm{~m}, 10 \mathrm{~m}, 16 \mathrm{~m}, 22 \mathrm{~m}$ and $40 \mathrm{~m}$. A sampling cycle was completed every 30 min with a sampling frequency of $2 \mathrm{~Hz}$. 


\section{Collection and determination of plant and soil water in different forest types}

Based on the stable isotope profile measurement system, 5 transects $(30 \times 150 \mathrm{~m})$ were set up to the foot of the mountain according to the changes of forest types. the average canopy density of RL, LL, PL, BL and SL were $0.75,0.85,0.80,0.75$ and 0.65 , respectively, 5 sampling points were selected from each transects, and the branches and soil of different forest types were sampled at each point. During the ET peak period of Larix gmelinii ecosystem, the typical sunny days of June 15th, June 25th, July 4th, July 14 th and July 24 th were selected and sampled at points of different forest types during daytime. The non green annual branches of Larix gmelinii, Rhododendron dauricum, Ledum palustre and Betula fruticosa were cut, in order to avoid isotope fractionation caused by plant transpiration, the bark was quickly stripped and put into the sampling bottle. Cut the non green root and stem joint of Pyrola incarnata and Sphagnum palustre and quickly put them into the sampling bottle. Under the plants sampled, soil samples of $5 \mathrm{~cm}$ and $10 \mathrm{~cm}$ were collected by soil drill, and quickly put into the sampling bottle. 6 replicates of each sample were sealed with para glue and stored in a portable refrigerator at 0 $5^{\circ} \mathrm{C}$, the samples were taken back to the laboratory, the samples were taken back to the laboratory, and the water in the branches was extracted from the Low - temperature Vacuum Extractor (Los Gatos research Inc., USA), and the oxygen isotope composition in the samples was detected by DLT-100 Liquid Water Isotope Analyzer (Los Gatos research Inc., USA), with a measurement accuracy of $\pm 0.2 \%$.

\section{Measurement of environmental factors}

The Vorticity Correlation System is also installed on the observation tower of the Water Wapor Stable Isotope Profile Measurement System, The system includes 3D ultrasonic anterometer (Model CSAT-3, Campbell Sci. Inc., USA), open infrared $\mathrm{CO}_{2} / \mathrm{H}_{2} \mathrm{O}$ gas analyzer (Model $\mathrm{LI}-7500, \mathrm{Li}-$ Cor Inc. , USA), 7 layers of air temperature, humidity (HMP45C, Vaisala, Finland) and water pressure (CS105, Vaisala, Finland) meters, which were installed at heights of 4, 8, 18, 38, 42, 50, $60 \mathrm{~m}$, respectively. The sensor for precipitation (TE525, Campbell Sci. Inc., USA) and wind (W200P, Campbell Sci. Inc., USA) were located at 60m (7th Floor). Soil temperature (TCVA, Campbell Sci. Inc., USA) and soil moisture (CS616-L50, Campbell Sci. Inc., USA) were observed at the depths of 5,10,20,40,80cm respectively. There are two infrared temperature probes for collecting trunk and canopy temperatures, and the observations sensor for radiation, evaporation, snow depth and hours of daylight with sampling frequency of $0.5 \mathrm{~Hz}$ via the data collector (CR1000, Campbell Sci. Inc., USA) automatically records every $30 \mathrm{~min}$.

\section{Data analysis}

In the process of $\mathrm{E}$ and $\mathrm{T}$, stable hydrogen and oxygen isotopes in the water vapor produced will undergo 
equilibrium fractionation and dynamic fractionation. The heavy isotope composition of water vapor from $\mathrm{E}$ is depleted relative to soil water, $\mathrm{T}$ enriches the heavy isotope of leaf water, when $\mathrm{T}$ is strong or is in ISS, the isotopic composition of $\mathrm{T}$ water vapor is close to that of xylem water (Flanagan et al. 1991; Wang et al. 2000), therefore, there is a significant difference in hydrogen and oxygen stable isotope composition between $\mathrm{E}$ with high fractionation and $\mathrm{T}$ with less fractionation, this is the theoretical basis for the quantitative differentiation of ecosystem ET by stable hydrogen and oxygen isotopes (Yepez et al. 2003; Williams et al. 2004). In the natural environment, water is composed of hydrogen and oxygen isotopes, the oxygen isotope ratio is expressed as the mole ratio of $\mathrm{H}_{2}{ }^{18} \mathrm{O}$ to $\mathrm{H}_{2}{ }^{16} \mathrm{O}$, the output of the results is based on the Vienna Standard Mean Ocean Water $(\mathrm{V}-$ SMOW), which is represented by $\delta$ :

$$
\delta^{18} O=\left(\frac{R_{\text {sample }}}{R_{\text {standard }}}-1\right) \times 1000
$$

$R_{\text {sample }}$ and $R_{\text {standard }}$ are the molar ratios of ${ }^{18} \mathrm{O} /{ }^{16} \mathrm{O}$ of sample and standard, respectively.

\section{Estimation of soil evaporation water vapor $\delta^{18} \mathrm{O}$}

In the process of soil evaporation, $\mathrm{H}_{2}{ }^{16} \mathrm{O}$ is easier to evaporate through the soil surface than $\mathrm{H}_{2}{ }^{18} \mathrm{O}$, which leads to the enrichment of ${ }^{18} \mathrm{O}$ in soil evaporation surface. The movement pattern of soil water, recharge path and preferential flow caused by soil heterogeneity will affect the characteristics of soil water oxygen isotope (Gazis et al. 2004; Phillips et al. 2005). The oxygen isotope composition of $\mathrm{E}$ water vapor $\left(\delta^{18} \mathrm{O}_{E}\right)$ can be calculated by Craig-Gordon model (Yakir et al. 2000; Griffis et al. 2005):

$$
\delta^{18} O_{E}=\frac{\delta^{18} O_{\text {soil }} / \alpha_{\text {soil }}^{+}-R H \cdot \delta^{18} O_{v-\text { soil }}-\varepsilon_{\text {soil }}-(1-R H) \varepsilon_{k}}{(1-R H)-(1-R H) \varepsilon_{k} / 1000}
$$

$\delta^{18} O_{\text {soil }}$ is the oxygen isotope composition of water vapor on the soil evaporation surface, $\delta^{18} O_{v-\text { soil }}$ is the oxygen isotope composition of atmospheric water vapor near the ground, $R H$ is the relative humidity of air in the forest, ${ }^{18} \mathrm{O \alpha}^{+}{ }_{\text {soil }}(>1)$ is the soil equilibrium fractionation coefficient related to soil temperature, $\varepsilon_{\text {soil }}$ is the equilibrium fractionation effect of soil, and $\varepsilon_{k}$ is the dynamic fractionation coefficient of 1.0164 (Cappa et al. 2003). The ${ }^{18} \mathrm{O \alpha}^{+}$soil was calculated according to the soil surface temperature:

$$
{ }^{18} \mathrm{O} \alpha_{\text {soil }}^{+}=\frac{1.137\left(10^{6} / T_{\text {soil }}{ }^{2}\right)-0.4516\left(10^{3} / T_{\text {soil }}\right)-2.0667}{1000}+1
$$

$T_{\text {soils }}$ is the absolute temperature ( $\mathrm{k}$ ) of soil $5 \mathrm{~cm}$ deep.The $\varepsilon_{\text {soil }}$ was (Yakir et al. 2000):

$$
\varepsilon_{\text {soil }}=\left(1-\frac{1}{{ }^{18} \mathrm{O} \alpha_{\text {soil }}^{+}}\right)
$$




\section{Estimation of plant transpiration water vapor $\delta^{18} O$ in steady state}

In the study of quantitative differentiation of ET, it is assumed that under the condition of "ISS", that is, the oxygen isotope composition of $\mathrm{T}$ water vapor $\left(\delta^{18} \mathrm{O}_{T}\right)$ is consistent with the isotope ratio of branch water $\left(\delta^{18} \mathrm{O}_{\text {branch }}\right.$ ), the transpiration rate of plants is fast in the afternoon, and the turnover of water in the vein and the transpiration rate on the surface of stomatal cavity were in equilibrium (Welp et al. 2008), therefore, the $\delta^{18} O_{T}$ was (Sun et al. 2015):

$$
\delta^{18} O_{T}=a \delta^{18} O_{b r a n c h}^{a}+(1-a) O_{b r a n c h}^{b}
$$

$a$ is canopy density, $\delta^{18} \mathrm{O}^{a}{ }_{\text {branch }}$ and $\delta^{18} \mathrm{O}^{b}{ }_{\text {branch }}$ are oxygen isotopic compositions of $\mathrm{T}$ water vapor of trees and shrubs, respectively.

\section{Estimation of evapotranspiration water vapor $\delta^{18} O$ of ecosystem}

The oxygen isotope composition $\left(\delta^{18} O_{E T}\right)$ of ecosystem ET was estimated by using Flux-Profile method, assuming that $\mathrm{H}_{2}{ }^{16} \mathrm{O}$ and $\mathrm{H}_{2}{ }^{18} \mathrm{O}$ have the same turbulent diffusivity (Griffis et al. 2005; Lee et al. 2007), the Keeling Plot equation was obtained by using water vapor concentration and water vapor isotope composition, and its intercept was $\delta^{18} O_{E T}$ (Yepez et al. 2003; Williams et al. 2004):

$$
\delta^{18} O_{e}=C_{b}\left(\delta^{18} O_{b}-\delta^{18} O_{E T}\right)\left(\frac{1}{C_{e}}\right)+\delta^{18} O_{E T}
$$

$C_{e}$ and $\delta^{18} O_{e}$ are the water vapor concentration and oxygen isotope composition in the air of the ecosystem, respectively, while $C_{b}$ and $\delta^{18} O_{b}$ are the water vapor concentration and oxygen isotope composition in the background atmosphere, respectively. Estimation of contribution rate of $\mathrm{T}\left(F_{T}\right)$ to ET using binary linear mixed model (Yakir et al. 2000):

$$
F_{T}=\frac{\delta^{18} O_{E T}-\delta^{18} O_{E}}{\delta^{18} O_{T}-\delta^{18} O_{E}}
$$

\section{Results}

\section{Changes of meteorological factors during observation}

During the observation period, the main meteorological factors changed (Fig. 2). The 5 observation days were sunny, with the highest temperatures of $19.97^{\circ} \mathrm{C}, 19.88^{\circ} \mathrm{C}, 23.04^{\circ} \mathrm{C}, 20.09^{\circ} \mathrm{C}$ and $19.23^{\circ} \mathrm{C}$, and the lowest relative humidity were $43.25 \%, 51.32 \%, 55.4 \%, 42.82 \%$ and $37.78 \%$, respectively, high temperature and low humidity are favorable for $\mathrm{E}$ and $\mathrm{T}$. The maximum solar radiation were $632.42 \mathrm{~W} / \mathrm{m}^{2}, 779.98 \mathrm{~W} / \mathrm{m}^{2}, 746.93 \mathrm{~W} / \mathrm{m}^{2}, 667.57$ 
$\mathrm{W} / \mathrm{m}^{2}$ and $554.86 \mathrm{~W} / \mathrm{m}^{2}$, respectively, when the solar radiation is strong, on the one hand, it is conducive to the opening of leaf stomata to promote $\mathrm{T}$, on the other hand, it can increase leaf surface temperature and accelerate $\mathrm{T}$. And the maximum wind speeds were $1.71 \mathrm{~m} / \mathrm{s}, 1.59 \mathrm{~m} / \mathrm{s}, 2.01 \mathrm{~m} / \mathrm{s}, 1.67 \mathrm{~m} / \mathrm{s}$ and $1.79 \mathrm{~m} / \mathrm{s}$, respectively, when the wind speed is high, it is conducive to the diffusion of water vapor, thus promoting T. The environmental conditions of the 5 observation days were relatively consistent, all of them belonged to high temperature, low humidity and strong radiation weather, which conformed to ISS hypothesis, which reduced the uncertainty of quantitative differentiation of ET to a certain extent.
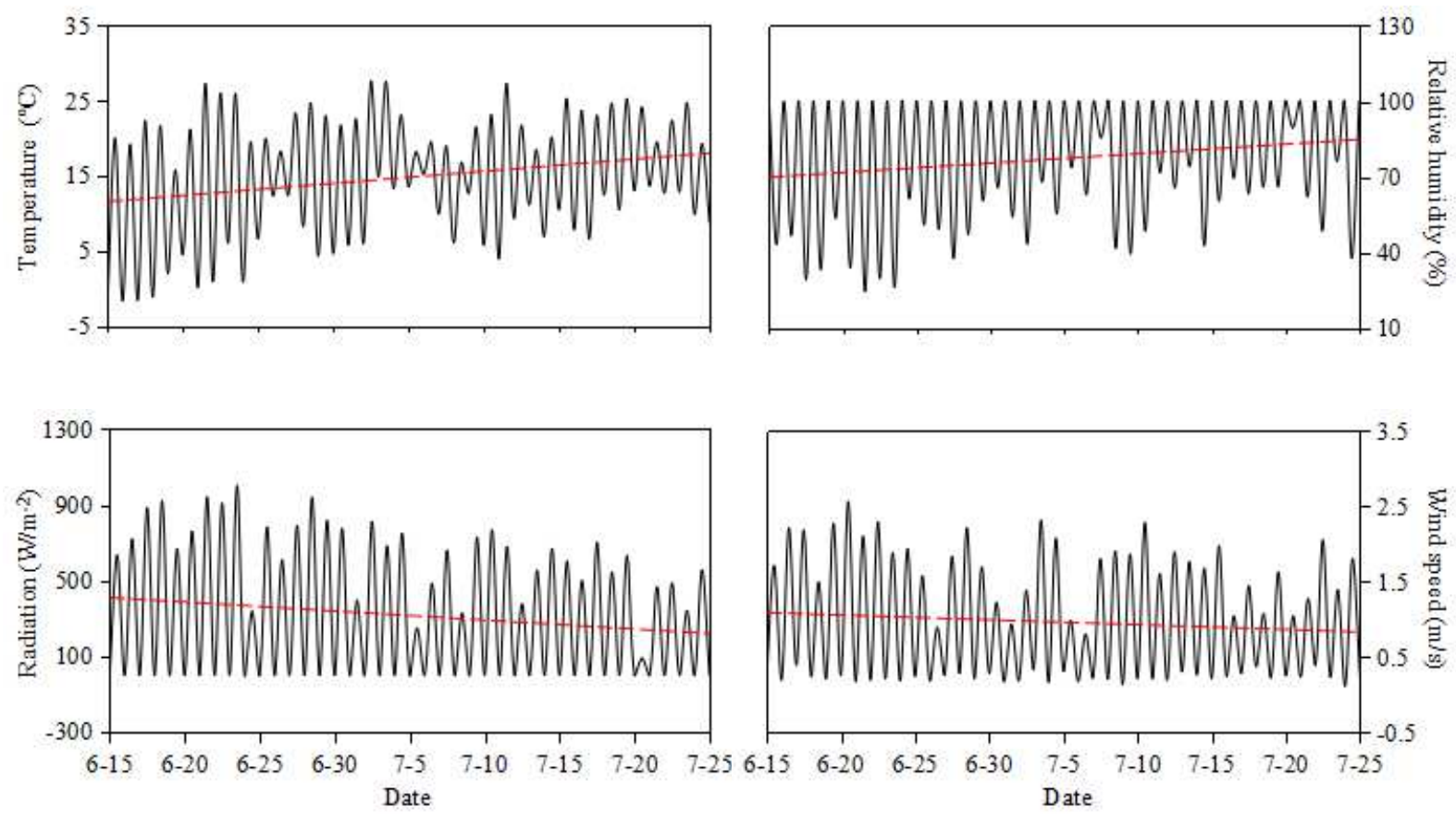

Fig. 2 Changes in environmental factors during observation.

\section{Changes of water vapor concentration and its $\delta^{18} \mathrm{O}$ in different vertical gradients of ecosystem}

The diurnal variation trend of water vapor concentration in the 5 observation days is complex, and there is a big difference, on the whole, it presents a "V" diurnal variation trend of "high-low-high" (Fig. 3, left), the minimum appeared at 15:00, 14:00, 11:00, 12:00 and 17:00, the maximum appeared at 07:00, 09:00, 04:00, 11:00 and 15:00, respectively, and the maximum difference of water vapor concentration were $1.55 \mathrm{mmol} / \mathrm{mol}, 1.16$ $\mathrm{mmol} / \mathrm{mol}, 1.28 \mathrm{mmol} / \mathrm{mol}, 1.89 \mathrm{mmol} / \mathrm{mol}$ and $1.75 \mathrm{mmol} / \mathrm{mol}$, respectively. The water vapor concentrations on different vertical gradients on the same observation day have similar trends and obvious differences, and the difference is more obvious during the daytime. The gradient order of water vapor concentration from large to small is: near surface layer, upper shrub, lower canopy, middle canopy, upper canopy and background atmosphere. 

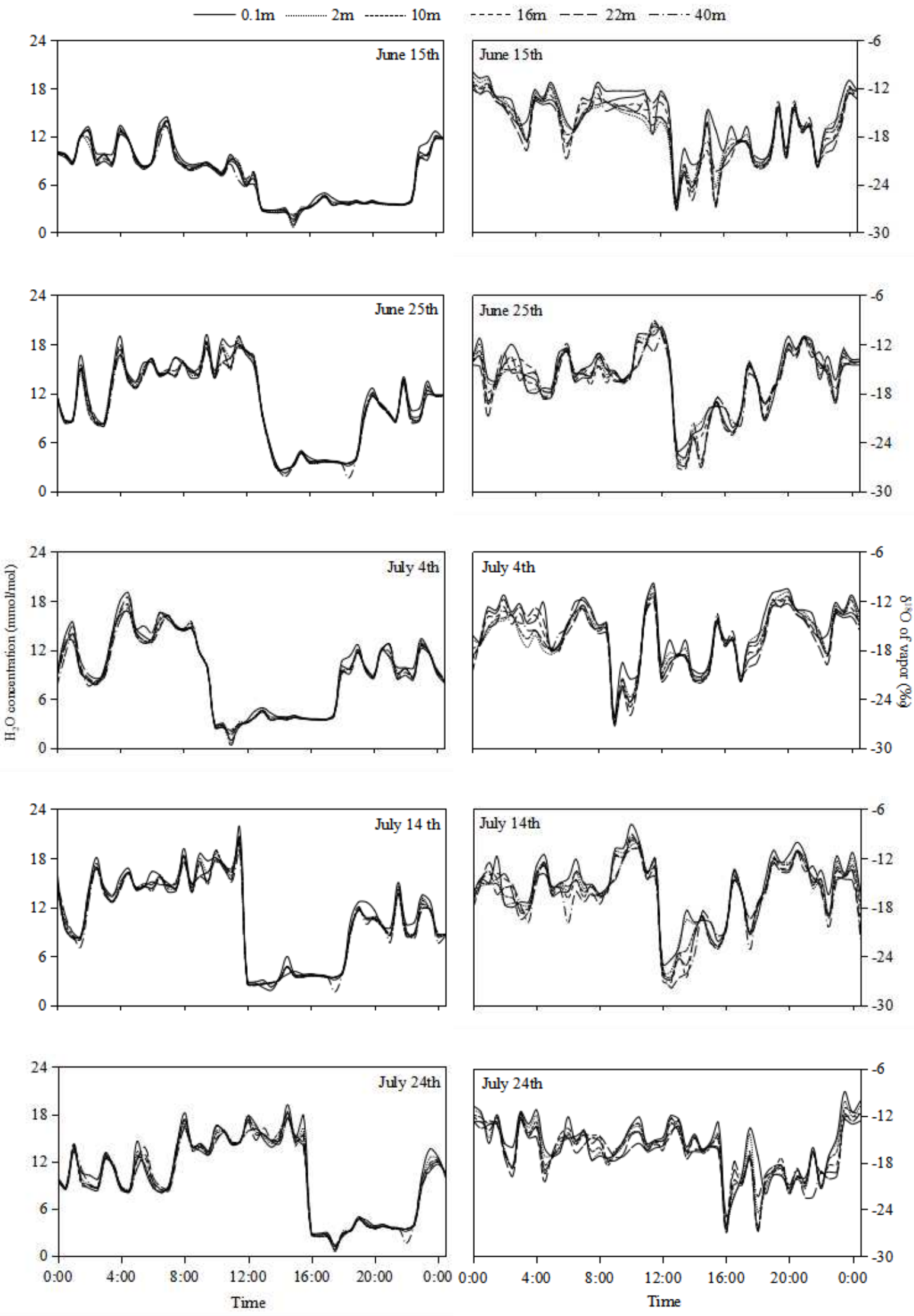

Fig. 3. Diurnal variation of water vapor concentration (left) and $\delta^{18} O$ (right) at different gradients of Larix gmelinii ecosystem.

The diurnal variation trend of water vapor $\delta^{18} O$ in the 5 observation days is relatively consistent with that of 
water vapor concentration, on the whole, it shows a "V" diurnal variation trend of "high—low-high" (Fig. 3, right), the minimum appeared at 13:00, 13:00, 09:00, 12:00 and 16:00, and the maximum appeared at 00:00, 11:00, 11:00, 10:00 and 23:00, respectively. On the same observation day, the variation trend of water vapor $\delta^{18} O$ on different gradients is relatively consistent, and there are obvious differences between gradients, water vapor $\delta^{18} \mathrm{O}$ shows a decreasing trend with the increase of gradient, the average difference of water vapor $\delta^{18} \mathrm{O}$ between the near surface layer and the background atmosphere is about $0.92 \%$, that between the upper shrub and the upper canopy is about $0.37 \%$, that between the lower canopy and the middle canopy is about $0.05 \%$, and that of middle canopy and upper canopy is about $0.18 \%$.

\section{Changes of soil evaporation and plant steady state transpiration in different forest types}

Table 1 Calculation parameters of Craig-Gordon equation.

\begin{tabular}{|c|c|c|c|c|c|c|}
\hline Date & Time & $\begin{array}{l}\text { Relative humidity } \\
\qquad( \pm \text { SD }) 1 \%\end{array}$ & $\begin{array}{l}\text { Absolute temperature } \\
\qquad( \pm \mathrm{SD}) / \mathrm{K}\end{array}$ & $\begin{array}{c}\delta^{18} O_{v-\text { soil }} \\
\quad / \%\end{array}$ & ${ }^{18} \mathrm{O} \alpha^{+}{ }_{\text {soil }}$ & $\varepsilon_{\text {soil }}$ \\
\hline \multirow{3}{*}{$06-15$} & 06: $00-10: 00$ & $71.16 \pm 18.29$ & $281.47 \pm 1.41$ & $-14.84 \pm 1.24$ & 1.0107 & 0.0107 \\
\hline & 10: $00-14: 00$ & $46.53 \pm 2.64$ & $289.98 \pm 1.83$ & $-16.09 \pm 6.82$ & 1.0099 & 0.0099 \\
\hline & 14: $00-18: 00$ & $53.94 \pm 8.68$ & $290.98 \pm 0.45$ & $-19.58 \pm 2.64$ & 1.0098 & 0.0098 \\
\hline \multirow{3}{*}{$06-25$} & 06: $00-10: 00$ & $99.20 \pm 1.12$ & $286.14 \pm 0.11$ & $-15.78 \pm 2.12$ & 1.0102 & 0.0102 \\
\hline & 10: $00-14: 00$ & $80.20 \pm 8.94$ & $290.00 \pm 1.96$ & $-17.03 \pm 5.11$ & 1.0099 & 0.0099 \\
\hline & 14: $00-18: 00$ & $83.93 \pm 5.36$ & $291.29 \pm 0.24$ & $-18.62 \pm 2.37$ & 1.0098 & 0.0098 \\
\hline \multirow{3}{*}{$07-04$} & $06: 00-10: 00$ & $82.57 \pm 8.78$ & $289.69 \pm 0.72$ & $-16.61 \pm 4.77$ & 1.0099 & 0.0099 \\
\hline & 10: $00-14: 00$ & $80.11 \pm 13.84$ & $292.72 \pm 1.17$ & $-17.08 \pm 4.11$ & 1.0097 & 0.0097 \\
\hline & 14: $00-18: 00$ & $86.88 \pm 5.83$ & $293.24 \pm 0.18$ & $-18.61 \pm 2.83$ & 1.0096 & 0.0096 \\
\hline \multirow{3}{*}{$07-14$} & $06: 00-10: 00$ & $98.54 \pm 2.44$ & $287.90 \pm 0.52$ & $-15.19 \pm 2.91$ & 1.0101 & 0.0101 \\
\hline & 10: $00-14: 00$ & $88.60 \pm 3.74$ & $293.18 \pm 3.22$ & $-17.20 \pm 5.83$ & 1.0096 & 0.0096 \\
\hline & 14: $00-18: 00$ & $80.24 \pm 4.24$ & $293.66 \pm 1.29$ & $-18.51 \pm 3.05$ & 1.0096 & 0.0096 \\
\hline \multirow{3}{*}{$07-24$} & $06: 00-10: 00$ & $98.60 \pm 2.63$ & $287.87 \pm 0.13$ & $-16.49 \pm 1.99$ & 1.0101 & 0.0101 \\
\hline & 10: $00-14: 00$ & $80.59 \pm 4.49$ & $288.85 \pm 0.39$ & $-17.11 \pm 1.62$ & 1.0100 & 0.0100 \\
\hline & 14: $00-18: 00$ & $83.93 \pm 4.36$ & $289.52 \pm 0.03$ & $-18.25 \pm 4.16$ & 1.0099 & 0.0099 \\
\hline
\end{tabular}


$\square \mathrm{RL} \square \mathrm{LL} \square \mathrm{PL}$
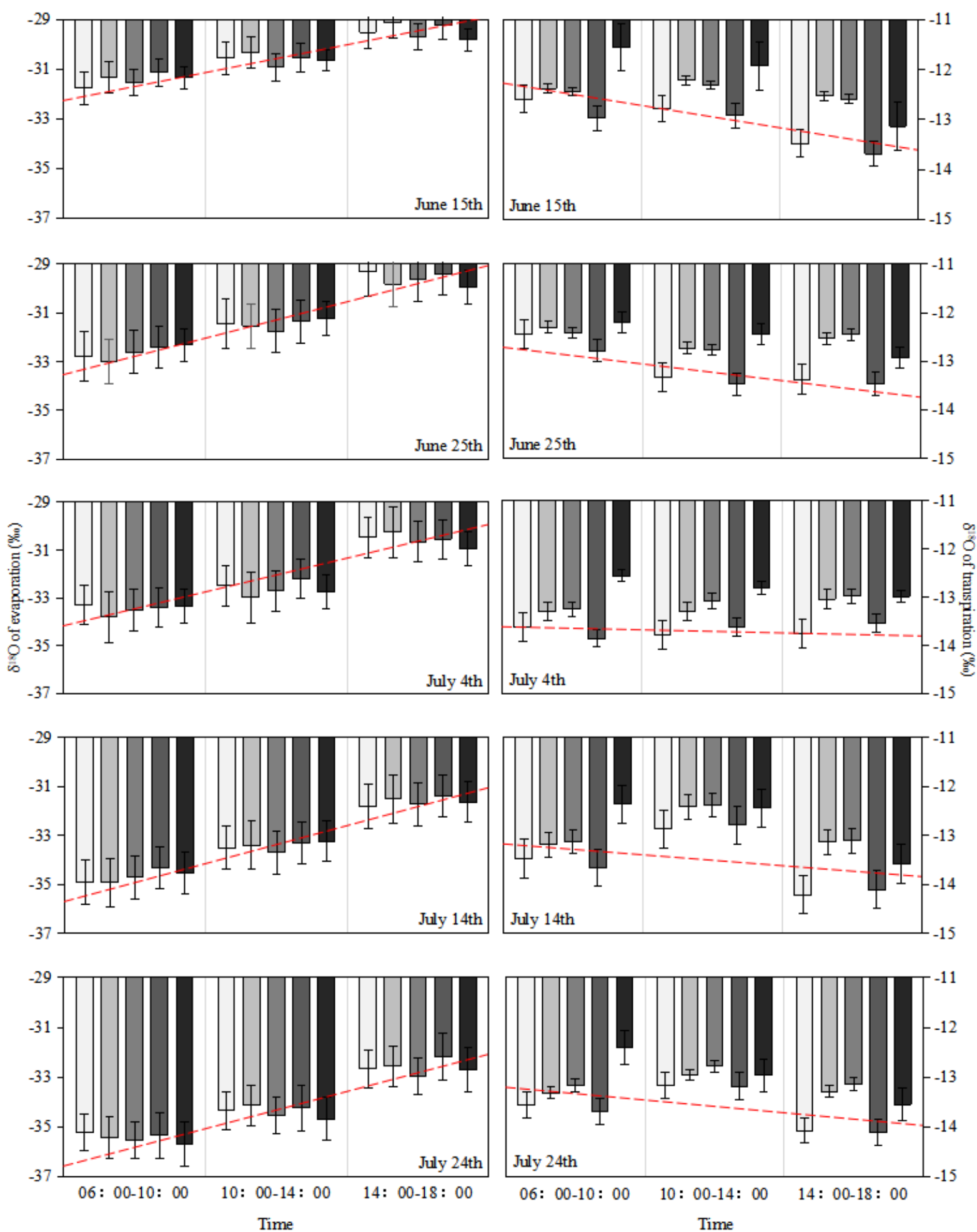

Fig. 4. Changes of $\delta^{18} \mathrm{O}$ in soil evaporation (left) and plant transpiration (right) of different forest types.

The oxygen isotope equilibrium fractionation coefficients of surface soil moisture in the process of $\mathrm{E}\left({ }^{18} \mathrm{O} \alpha^{+}\right.$soil $)$in Larix gmelinii forest were between 1.0096 and 1.0107 (Table 1), and the equilibrium fractionation effect $\left(\varepsilon_{\text {soil }}\right)$ ranged from 0.0096 to 0.0107 , both of which were 06:00-10:00>10:00-14:00>14:00-18:00, and $\varepsilon_{\text {soil }}$ was in direct proportion to ${ }^{18} \mathrm{O \alpha}^{+}{ }_{\text {soil }}$. The variation trend of composition of water vapor near the surface $\left(\delta^{18} \mathrm{O}_{v-\text { soil }}\right)$ was 
06:00-10:00>10:00-14:00>14:00-18:00.

Using Craig-Gordon model, the oxygen isotope composition of E water vapor $\left(\delta^{18} O_{E}\right)$ in Larix gmelinii forest was obtained, the $\delta^{18} O_{E}$ of the 5 observation days ranged from $-35.71 \%$ to $-29.12 \%$ (Fig. 4, left), which was smaller than the oxygen isotope composition of soil surface water $\left(\delta^{18} O_{\text {soil }}\right)\left(-15.16 \%_{0}--10.19 \%\right)$, it shows that $\delta^{18} \mathrm{O}$ of E water vapor is obviously depleted. The $\delta^{18} O_{E}$ is increasing in daily scale, and the daily variation range is less than $3.69 \%$, and July $24>$ June $25>$ June $15>$ July $4>$ July 14 . Among the 5 forest types, the order of $\delta^{18} O_{E}$ from large to small was SL, LL, BL, RL and PL, the maximum difference of $\delta^{18} O_{E}$ was $1.08 \%$.

During the 5 observation days, the oxygen isotope composition of steady state T water vapor $\left(\delta^{18} O_{T}\right)$ ranged from $-14.22 \%$ to $-11.21 \%$ (Fig. 4 , right), which was significantly lower than that of plant branch water $\left(\delta^{18} \mathrm{O}_{\text {branch }}\right)(-13.39 \%--3.47 \%$ ) $<$ Betula fruticosa $(-11.37 \% \mathrm{0} \pm 0.33 \% \mathrm{o})<$ Rhododendron dauricum $(-10.89 \% \mathrm{0} \pm 0.98 \% \mathrm{o})<$ Ledum palustre $(-$ $10.12 \% 0 \pm 1.05 \%)<$ Pyrola incarnat $(-9.79 \%$ $\pm 0.62 \%$ o $)<$ Sphagnum palustre $(-4.85 \%$ $\pm 0.93 \%$ ). On the daily scale, $\delta^{18} O_{T}$ is decreasing, contrary to the trend of $\delta^{18} O_{E}$, the daily variation range is less than 3.01\%, and June $25>$ July $4>$ July $24>$ July $14>$ June 15 . Among the 5 forest types, the order of $\delta^{18} O_{T}$ from large to small was SL, PL, LL, RL and BL, the maximum difference of $\delta^{18} O_{T}$ was $2.13 \%$.

\section{Changes and quantitative differentiation of ecosystem evapotranspiration}

The oxygen isotope composition of ET water vapor $\left(\delta^{18} \mathrm{O}_{E T}\right)$ of Larix gmelinii ecosystem is obtained by using Keeling equation of water vapor concentration and isotopic composition in the upper canopy at the same time, the fitting results of Keeling equation showed that(Table 2), the Keeling equation reached a very significant level $(P<$ 0.01 ) at 06:00 - 10:00 on June 25, July 14 and July 24, 10:00-14:00 on June 15, June 25, July 4, July 14 and July 24 , and 14:00-18:00 on July 4, in the rest of the time, it did not reach the significant level. The $\delta^{18} O_{E T}$ of the 5 observation days shows an "inverted V" shaped trend, which increased first and then decreases, and was larger in the afternoon than in the morning, and the maximum values appeared in the time period of 10:00-14:00.

Among the 5 observation days, E was the strongest during 06:00-10:00, accounting for the largest proportion of ET (Fig. 5, left), with an average of $40.25 \%, 37.42 \%, 27.93 \%, 41.41 \%$ and $46.66 \%$, which was significantly higher than that of E ratio $\left(F_{E}\right)$ during 10:00-14:00 and 14:00-18:00, showing a "V" trend, among them, the $F_{E}$ on July 24 was the largest. T accounted for the largest proportion of ET between 10:00 and 14:00, (Fig. 5, right), with an average of $83.18 \%, 91.71 \%, 96.42 \%, 86.47 \%$ and $79.41 \%$, which was significantly higher than that of $\mathrm{T}$ ratio $\left(F_{T}\right)$ during 06:00-10:00 and 14:00-18:00, showing an "inverted V"shaped trend, among them, the $F_{T}$ on July 4 was the largest. In general, the contribution rate of transpiration of Larix gmelinii, Rhododendron dauricum, 
Ledum palustre, Betula fruticosa, Pyrola incarnata and Sphagnum palustre to the evapotranspiration of the ecosystem was $74.58 \pm 12.68 \%$, which indicated that the ET of Larix gmelinii ecosystem mainly came from T. The $F_{T}$ of 5 forest types ranged from $51.01 \%$ to $98.72 \%$, which was significantly higher than that of $F_{E}(1.28 \%-$ $48.99 \%)$, the change range of $F_{T}$ in BL was $(75.49 \% \pm 2.06 \%)>\operatorname{RL}(74.72 \% \pm 2.12 \%)>\operatorname{PL}(72.62 \% \pm 2.01 \%)>$ $\operatorname{SL}(72.42 \% \pm 2.78 \%)>\operatorname{LL}(72.35 \% \pm 1.99 \%) . F_{E}$ was opposite.

Table 2 Regression analysis of Keeling Plot equation and variation of oxygen isotope composition of ecosystem evapotranspiration.

\begin{tabular}{|c|c|c|c|c|c|c|c|c|}
\hline \multirow{2}{*}{ Date } & \multirow{2}{*}{ Time } & \multirow{2}{*}{ Keeling Plot } & \multirow{2}{*}{$\begin{array}{c}\text { Coefficient } \\
R^{2}\end{array}$} & \multirow{2}{*}{$\begin{array}{c}\text { Significance } \\
P\end{array}$} & \multirow{2}{*}{$\begin{array}{c}\text { Number } \\
n\end{array}$} & \multicolumn{2}{|c|}{ C.I. $(95 \%)$ for intercept } & \multirow{2}{*}{$\delta^{18} O_{E T}$} \\
\hline & & & & & & lower & upper & \\
\hline \multirow{3}{*}{$06-15$} & 06: $00-10: 00$ & $y=0.07 x-19.85$ & 0.01 & 0.31 & 144 & -20.89 & -18.82 & -19.85 \\
\hline & $10: 00-14: 00$ & $y=0.43 x-15.76$ & 0.31 & $<0.01$ & 144 & -18.75 & -12.63 & -15.76 \\
\hline & 14: $00-18: 00$ & $y=0.11 x-19.46$ & 0.03 & 0.19 & 144 & -21.64 & -17.29 & -19.46 \\
\hline \multirow{3}{*}{$06-25$} & 06: $00-10: 00$ & $y=0.32 x-18.82$ & 0.12 & $<0.01$ & 144 & -22.21 & -12.43 & -18.82 \\
\hline & 10: $00-14: 00$ & $y=-0.91 x-14.62$ & 0.71 & $<0.01$ & 144 & -17.29 & -11.96 & -14.62 \\
\hline & 14: $00-18: 00$ & $y=0.04 x-18.22$ & 0.02 & 0.45 & 144 & -21.52 & -15.18 & -18.22 \\
\hline \multirow{3}{*}{$07-04$} & $06: 00-10: 00$ & $y=-0.05 x-18.73$ & 0.01 & 0.28 & 144 & -23.13 & -14.34 & -18.73 \\
\hline & $10: 00-14: 00$ & $y=-0.94 x-14.03$ & 0.84 & $<0.01$ & 144 & -16.61 & -11.45 & -14.03 \\
\hline & 14: $00-18: 00$ & $y=0.53 x-16.12$ & 0.43 & $<0.01$ & 144 & -20.62 & -11.63 & -16.12 \\
\hline \multirow{3}{*}{$07-14$} & $06: 00-10: 00$ & $y=0.52 x-20.86$ & 0.49 & $<0.01$ & 144 & -24.08 & -17.64 & -20.86 \\
\hline & $10: 00-14: 00$ & $y=0.94 x-16.35$ & 0.89 & $<0.01$ & 144 & -20.35 & -12.34 & -16.35 \\
\hline & 14: $00-18: 00$ & $y=0.07 x-19.52$ & 0.01 & 0.39 & 144 & -23.47 & -15.56 & -19.52 \\
\hline \multirow{3}{*}{$07-24$} & $06: 00-10: 00$ & $y=0.45 x-21.78$ & 0.36 & $<0.01$ & 144 & -25.19 & -18.37 & -21.78 \\
\hline & 10: $00-14: 00$ & $y=-0.87 x-16.39$ & 0.82 & $<0.01$ & 144 & -19.33 & -13.45 & -16.39 \\
\hline & 14: $00-18: 00$ & $y=0.09 x-19.94$ & 0.01 & 0.29 & 144 & -23.75 & -16.13 & -19.94 \\
\hline
\end{tabular}



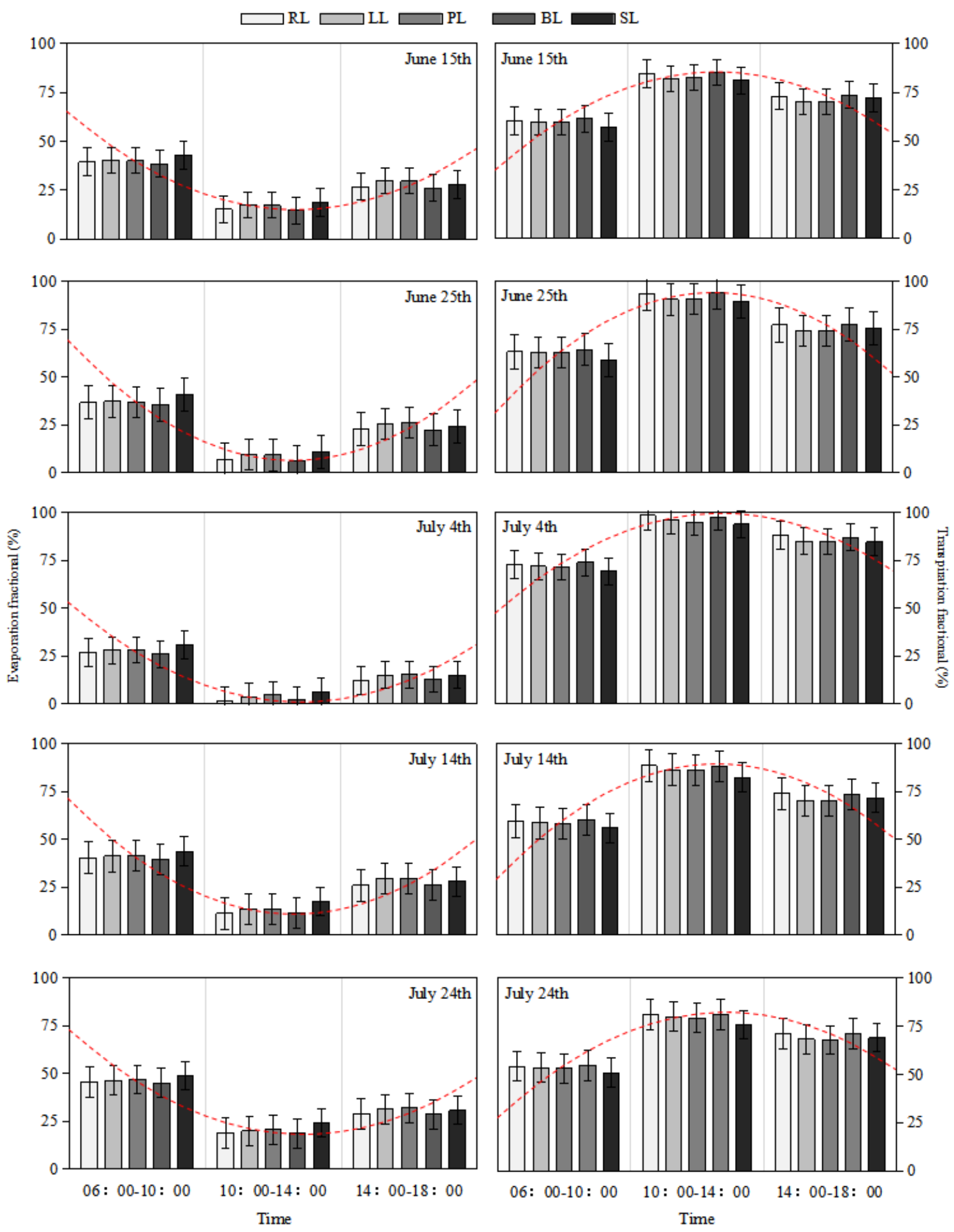

Fig. 5. Proportion of soil evaporation (left)/plant transpiration (right) to ecosystem evapotranspiration in different forest types.

\section{Discussion}

\section{Variation of $\delta^{18} O$ in water vapor with different vertical gradients in ecosystem}

The water vapor concentration and its oxygen isotope composition $\delta^{18} O$ are not only affected by plant 
physiological characteristics and growth status, but also affected by many factors such as regional environment and climate conditions, there are certain variability in time and space (Komatsu et al. 2007; Oishi et al. 2008). The results showed that the water vapor concentration and $\delta^{18} O$ of Larix gmelinii ecosystem showed a "V" diurnal variation trend, the minimum values appeared between 11:00 and 17:00, significantly lower than that in the morning and evening, which was similar to the results of Lai et al. (2006) on coniferous forest in southern Washington. The diurnal variation range of $\delta^{18} \mathrm{O}$ in Larix gmelinii ecosystem ranged from 8 to $11 \%$, which was significantly higher than that of deciduous forest in southern Canada by 2\%o (Liu et al. 2017), which may be related to strong transpiration in sunny days, higher latitude and air turbulence. The water vapor $\delta^{18} O$ of 6 vertical gradients in Larix gmelinii ecosystem has obvious differences, and the water vapor $\delta^{18} O$ shows a decreasing trend with the increase of gradient, which is consistent with the results of Sun et al. (2015) in the study of deciduous forest in central China. The average difference of water vapor $\delta^{18} O$ between the near surface layer and the background atmosphere of Larix gmelinii ecosystem is about $0.92 \%$, that between the upper shrub and the upper canopy is about $0.37 \%$, that between the lower canopy and the middle canopy is about $0.05 \%$, and that of middle canopy and upper canopy is about $0.18 \%$. It may be that the water vapor $\delta^{18} O$ in the near surface layer mainly comes from the evaporation of the soil water in the surface layer, the water vapor $\delta^{18} O$ in the upper shrub mainly comes from the transpiration of the shrub, and the water vapor $\delta^{18} O$ in the upper, middle and lower canopy mainly comes from the tree transpiration, the water vapor $\delta^{18} O$ source of each gradient is different, with the increase of the vertical gradient, the diffusion resistance of water vapor is different, the process of $\delta^{18} O$ diffusion and fractionation exists due to canopy interception and evaporation, which results in the decrease of water vapor $\delta^{18} O$ with the increase of height.

\section{Estimation of soil evaporation and plant steady state transpiration of different forest types}

The results show that the oxygen isotope composition of $\mathrm{E}$ water vapor $\left(\delta^{18} \mathrm{O}_{E}\right)$ of all forest types ranges from $35.71 \%$ to $-29.12 \%$, which is less than the oxygen isotope composition of soil surface water $\left(\delta^{18} O_{\text {soil }}\right)$, this is similar to the results obtained by Liu et al. (2017) on Platycladus orientalis in Beijing mountainous area, it may be related to the stable isotope fractionation in the process of evaporation of surface soil water from liquid water to vapor water. In the E process, the light isotope $\mathrm{H}_{2}{ }^{16} \mathrm{O}$ evaporates from the soil first than the heavy isotope $\mathrm{H}_{2}{ }^{18} \mathrm{O}$, resulting in the evaporation of water vapor $\delta^{18} O$ dilution, the remaining liquid water $\delta^{18} O$ enrichment. The $\delta^{18} O_{E}$ is increasing on the daily scale, it may be related to soil temperature, the increase of soil temperature can accelerate the rate of $\mathrm{E}$, resulting in the obvious depletion of $\delta^{18} O$ in evaporated water vapor. Among the 5 forest types, the order of $\delta^{18} O_{E}$ from large to small was SL, LL, BL, RL and PL, the maximum difference of $\delta^{18} O_{E}$ was $1.08 \%$. This may be related to the $\delta^{18} O$ in the surface soil water of each forest type, the elevation, slope, aspect 
and slope position of each forest type are different, and the $\delta^{18} O$ of surface soil water is different, therefore, there are some differences in isotope fractionation coefficient.

At present, the estimation of the oxygen isotope composition of $\mathrm{T}$ water vapor $\left(\delta^{18} \mathrm{O}_{T}\right)$ is based on the hypothesis of ISS. However, under the field conditions, T is often in NSS under daytime driven by atmospheric temperature, relative humidity, solar radiation and wind speed (Gazis et al. 2004), Wang et al. (2000) showed that it is difficult to achieve ISS in a short time scale by controlling relative humidity. The $\delta^{18} O$ of leaf water is not a constant, its daily variation range is between $4 \%-8 \%$ (Farquhar et al. 2005), and its variation range in growing season is about $15 \%$, the maximum deviation between $\delta^{18} O_{T}$ under ISS and that under NSS exceeds $20 \%$, especially at night (Lai et al. 2006). In the daytime with strong transpiration rate, $\delta^{18} O$ is closer to that of plant branch water (Flanagan et al. 1991). The results showed that the oxygen isotope composition of steady state T water vapor $\left(\delta^{18} O_{T}\right)$ ranged from $-14.22 \%$ to $-11.21 \%$, which was significantly lower than that of plant branch water $\left(\delta^{18} \mathrm{O}_{\text {branch }}\right)(-13.39 \%--3.47 \%$ ) is decreasing on the daily scale, contrary to the variation trend of $\delta^{18} O_{E}$, it may be related to solar radiation. The stronger solar radiation is conducive to T, which makes the T of water vapor $\delta^{18} O$ obviously depleted. Among the 5 forest types, the order of $\delta^{18} O_{T}$ from large to small was SL, PL, LL, RL and BL, which was significantly lower than that of farmland ecosystem $(-7.13 \%--6.47 \%$ ) (Yuan et al. 2010), it may be determined by the differences in plant structure, physiology and biochemistry.

\section{Estimation and quantitative differentiation of ecosystem evapotranspiration}

The results showed that the the oxygen isotope composition of ET water vapor $\left(\delta^{18} O_{E T}\right)$ of the 5 observation days showed an "inverted V" shaped trend, which increased first and then decreased, and was larger in the afternoon than in the morning, and the maximum values appeared in the period of 10:00-14:00, which was contrary to the change trend of ecosystem water vapor $\delta^{18} O$, and $\delta^{18} O_{E T}$ was much larger than that of ecosystem water vapor. It may be that isotope fractionation occurred in the process of T, and the transpiration of water vapor $\delta^{18} O$ was depleted (Lee et al. 2007; Welp et al. 2008). When the transpiration was the strongest at noon, the $\delta^{18} O$ depletion was the most serious, resulting in the $\delta^{18} O_{E T}$ significantly higher than that in the ecosystem water vapor. The basis of Keeling method to estimate $\delta^{18} O_{E T}$ is that the difference of water vapor concentration and its $\delta^{18} O$ in ecosystem -atmospheric boundary layer only comes from ecosystem evapotranspiration (Sun et al. 2005), but on the short time scale $(\mathrm{h} / \mathrm{d})$, there are many factors such as air mass advection, atmospheric entrainment and atmospheric precipitation that cause the variation of water vapor $\delta^{18} O$ (Yepez et al. 2005). The correlation coefficients of some Keeling equations between 06:00-10:00 and 14:00-18:00 are low, and do not reach significant correlation. It may be that 06:00-10:00 and 14:00-18:00 are in the initial stage of water vapor concentration decrease or 
increase, and Keeling method is unstable and non-linear in water vapor diffusion environment (Nickerson et al. 2009), which leads to deviation of $\delta^{18} O_{E T}$ estimation.

The difference of water vapor $\delta^{18} O$ from different sources provides a possibility to determine the contribution rate of $\mathrm{T}$ to ET. The results showed that the contribution rate of $\mathrm{T}\left(F_{T}\right)$ in Larix gmelinii ecosystem was the largest during 10:00-14:00, with an average of 79\%-96\%, which was similar to the results of the $F_{T}$ in Amazon Basin forest $76 \%-100 \%$ (Moreira et al. 1997), in semi arid grassland forest $85 \%-93 \%$ (Yepez et al. 2005), and in wheat field ecosystem 96\%-98\% (Wang et al. 1995), indicating that the ET mainly comes from T. The $F_{T}$ of 06:00-10:00 and 14:00-18:00 is significantly lower than that of 10:00-14:00, which may be related to the relative humidity. The humidity in the morning and afternoon is higher than that in the noon, and the high humidity environment is not conducive to T. Therefore, the transpiration rate of plants is lower than that of noon, and the $\delta^{18} O$ of $\mathrm{T}$ is higher than that of noon, which leads to the $F_{T}$ of morning and afternoon less than that of noon. Among the 5 forest types, the change range of $F_{T}$ in $\mathrm{BL}$ was $(75.49 \% \pm 2.06 \%)>\operatorname{RL}(74.72 \% \pm 2.12 \%)>$ $\operatorname{PL}(72.62 \% \pm 2.01 \%)>\operatorname{SL}(72.42 \% \pm 2.78 \%)>\operatorname{LL}(72.35 \% \pm 1.99 \%)$. On the whole, the $F_{T}$ in shrub dominated Larix gmelinii forest was higher than that in grass dominated forest type, and moss dominated forest type. It may be that the leaf area of shrub is larger than that of herb, which is conducive to T. To a certain extent, the height of shrub is higher than that of herb. The temperature increases with the increase of height, and the relative humidity decreases with the increase of height. The environment of high temperature and low humidity at the shrub canopy is conducive to T. The environment of low temperature and high humidity near the surface layer is inhibited by $\mathrm{E}$. Mosses are mainly distributed in the river beach, and the high humidity environment is not conducive to plant transpiration. However, LL was significantly lower than SL, which may be related to the differences in plant structure, physiology and biochemistry. There were abundant essential oils in the leaves of Ledum palustre, which inhibited the transpiration of leaves to a certain extent, so its $F_{T}$ was lower than that of SL.

\section{Conclusions}

During the vigorous growth period of Larix gmelinii ecosystem, (1) the variation trend of water vapor concentration and its $\delta^{18} \mathrm{O}$ in different vertical gradients of the ecosystem were relatively consistent, showing a "V" diurnal variation trend as a whole, and the water vapor $\delta^{18} O$ decreased with the increase of height. The $\delta^{18} O$ of ET water vapor of ecosystem showed an "inverted V" type diurnal variation trend, which was opposite to that of ecosystem water vapor $\delta^{18} O$. (2) The daily variation of $\delta^{18} O$ in different forest types and its components were significantly different. The $\delta^{18} \mathrm{O}$ of $\mathrm{E}$ water vapor of each forest type was increasing on a daily scale, and the variation range was between $-35.71 \%$ and $-29.12 \%$, which was less than that of soil surface water. The $\delta^{18} O$ 
of $\mathrm{T}$ vapor of all forest types decreased on a daily scale, contrary to the change trend of $\mathrm{E}$ water vapor. The variation range was $-14.22 \%$ - $-11.21 \%$, which was less than that of plant water. (3) From 10:00 to 14:00, the contribution of $\mathrm{T}$ to the ET of the ecosystem was the largest, with an average of $79 \%-96 \%$. It was the main source of ET of the ecosystem. The order of contribution rate of $\mathrm{T}$ of each forest type from large to small was BL $(75.49 \% \pm 2.06 \%), \operatorname{RL}(74.72 \% \pm 2.12 \%), \operatorname{PL}(72.62 \% \pm 2.01 \%), \operatorname{SL}(72.42 \% \pm 2.78 \%)$, LL $(72.35 \% \pm 1.99 \%)$ On the whole, the transpiration contribution in shrub dominated Larix gmelinii forest was higher than that in grass dominated forest type , and moss dominated forest type.

\section{Abbreviations}

ET: Ecosystem evapotranspiration; E: Soil evaporation; T: Plant transpiration; SPAC: Soil—Plant—Atmosphere Continuum; OA-ICOS: Off-Axis Integrated Cavity Output Spectroscopy; RL: Rhododendron dauricumLarix gmelinii forest; LL: Ledum palustre - Larix gmelinii fores; PL: Pyrola incarnata —Larix gmelinii forest; BL: Betula fruticosa-Larix gmelinii forest; SL: Sphagnum palustre-Larix gmelinii forest; $\delta^{18} O$ : Composition of water vapor isotopes; $\delta^{18} O_{E T}$ : Isotopic composition of evapotranspiration water vapor; $\delta^{18} O_{E}$ : Isotopic composition of evaporation water vapor; $\delta^{18} O_{T}$ : Isotopic composition of transpiration water vapor; $F_{T}$ : Contribution rate of transpiration; $F_{E}$ : Contribution rate of evaporation

\section{Acknowledgments}

Thanks for the support and help of the staff of the Inner Mongolia Daxing' anling Forest Ecosystem National Field Science Observatory, Genhe County, China and Inner Mongolia Daxing' anling Forestry Science and Technology Research Institute, Yakeshi County, China.

\section{Authors' Contributions}

Conceptualization, QZ and XZ. Field investigation, JY CS. and JW. Field sampling, XZ RW and YJ. Sample testing, XZ and JW. Data analysis, QZ, XZ, RW, YJ and JY. Writing - original draft preparation, QZ, XZ, RW, YJ, JY, CS and JW. Writing - review and editing, QZ and XZ. All authors read and approved the final manuscript.

\section{Funding}

This research was funded by the National Natural Science Foundation of China (Grant No. 32060262) and the National Key Research and Development Program of China (Grant No. 2017YFC0504003).

\section{Availability of data and materials}

The datasets generated and/or analyzed during the current study are not publicly available due [the data is a part of the author's graduation thesis] but are available from the corresponding author on reasonable request. 


\section{Ethics approval and consent to participate}

Not applicable.

\section{Consent for publication}

Not applicable.

\section{Competing interests}

The authors declare that they have no competing interests.

\section{Author details}

${ }^{1}$ Forestry College, Inner Mongolia Agriculture University, Hohhot 010019, China

${ }^{2}$ Inner Mongolia Daxing' anling Forest Ecosystem National Field Science Observatory, Genhe 022350, China

${ }^{3}$ Inner Mongolia Daxing' anling Forestry Science and Technology Research Institute, Yakeshi 022150, China

\section{References}

Yu GR, Zhang LM, Sun XM (2004) Research progress on carbon flux of terrestrial ecosystem in Asia. Chinese Science Series D: Earth Science 34: 15-29

Friend AD, Stevens AK, Konx RG, Canell MG (1997) A process-based, terrestrial biosphere model of ecosystem dynamics (Hybrid v3.0). Ecological Modelling 95: 249—287

Yuan GF, Zhang N, Sun XM (2010) In situ continuous determination of water vapor $\delta^{18} \mathrm{O}$ value and Keeling plot method to distinguish evapotranspiration components. Journal of Plant Ecology 34 (2): 170—178

Xu XW, Yu XX Jia GD Li HZ Lu WW, Liu ZQ (2017) A review of water and carbon flux partitioning and coupling in SPAC using stable isotope techniques. Chinese Journal of Applied Ecology 28(7): 2369—2378

Sun W, Lin GH, Chen SP (2005) The application of stability isotope technology and Keeling curve method in the study of carbon/water exchange in terrestrial ecosystems. Journal of Plant Ecology 29 (5): 851-862

Gat JR (1996) Oxygen and hydrogen isotopes in the hydro logic cycle. Annual Review of Earth and Planetary Sciences 24: $225-262$

Wen XF, Zhang SC, Sun XM (2008) Research progress on enrichment of $\mathrm{H}_{2}{ }^{18} \mathrm{O}$ in leaf water. Journal of Plant Ecology 32(4): 961-966

Wen XF, Sun XM, Zhang SC (2008) Continuous measurement of water vapor $\mathrm{D} / \mathrm{H}$ and ${ }^{18} \mathrm{O} /{ }^{16} \mathrm{O}$ isotope ratios in the atmosphere. Journal of Hydrology 349: 489-500 
Yepez EA, Williams DG, Scott RL, Lin GH (2003) Partitioning over story and under story evapotranspiration in a semiarid savanna woodland from the isotopic composition of water vapor. Agricultural and Forest Meteorology 119(1/2): 53-68

Francey RJ, Tans PP (1987) Latitudinal variation in ${ }^{18} \mathrm{O}$ of atmospheric $\mathrm{CO}_{2}$. Nature 327: 495-497

Lin GH (2013) Stable isotope ecology. Higher Education Press, Beijing

Lee XH, Kim K, Smith R (2007) Temporal variations of the ${ }^{18} \mathrm{O} /{ }^{16} \mathrm{O}$ signal of the whole-canopy transpiration in a temperate forest. Global Biogeochemical Cycles doi: 10.1029/2006GB002871

Brooks JR, Barnard HR, Coulombe R (2010) Ecohydrologic separation of water between trees and streams in a Mediterranean climate. Nature Geoscience 2010, 3(2): 100-104

Zhang SC, Wen XF, Wang JL (2010) The use of stable isotopes to partition evapotranspiration fluxes into evaporation and transpiration. Acta Ecologica Sinica 30(4): 201-209

Wang P, Song XF, Yuan RQ (2013) Study on water consumption of Summer Maize in North China based on stable hydrogen and oxygen isotopes. Journal of natural resources 28(3): 481-490

Brunel JP, Simpson HJ, Herczeg AL, Whtehead R Walker GR (1992) Stable isotope composition of water vapor as an indicator of transpiration fluxes from rice crops. Water Resources Research 28(5): 1407-1416

Good SP, Soderberg K, Wang LX, Caylor KK (2012) Uncertainties in the assessment of the isotopic composition of surface fluxes: a direct comparison of techniques using laser-based water vapor isotope analyzers. Journal of Geophysical Research doi: 10.1029/2011JD017168

Shi Y(2010) Analysis of ecological and hydration processes of forest ecosystems in the main advantages of tree species in the mountainous areas of Beijing. Beijing Forestry University $5-12$

Zheng QH, Wang B (2009) Application of stability isotope technology in the differentiation of carbon and water hydrates in forest ecosystems. Forestry Scientific Research 22 (1): 109-114

Sun SJ, Meng P, Zhang JS, He CX, Zheng N (2015) Diurnal variation of oxygen isotope and quantitative differentiation of evapotranspiration in Quercus variabilis ecosystem in low mountainous areas of north China. Acta Zoologica Sinica 35, (8): 2592-2601

Liu L, Jia GD, Yu XX, Zhang YE (2017) Diurnal variation and quantitative differentiation of evapotranspiration components $\delta^{18} \mathrm{O}$ of Platycladus orientalis in high growth season in mountainous areas of Beijing. Journal of Beijing Forestry University 39 (12): 61-70

Luo (1990) Community classification and productivity of main forest types of Larix gmelinii forest in Mangui 
Forestry Bureau of Inner Mongolia. Journal of Beijing Forestry University 12(3): $51-55$

Wang B, Chen BS, Yan HG, Niu X, Song DC, Du B, Liu R, Chen XM (2020) Research and value evaluation of forest and wetland ecosystem services in Greater Khingan Range key state owned forest administration of Inner Mongolia. China Forestry Press, Beijing

Zhang XS (1993) Vegetation climate classification system for studying global change. Quaternary study (2):169

Jiang YL, Zhou GS (2001) Carbon balance and global change of Larix gmelinii forest. Journal of Applied Ecology 12(4): $481-484$

Li F, Zhou G S, Cao MC (2006) Simulation of geographical distribution response of Larix gmelinii to climate change. Journal of Applied Ecology 17(12): 2255-2260

Leng WF, He HS, Liu HJ (2008) Response of larch species to climate changes. Journal of Plant Ecology 1(3): $203-205$

Li XM, Zhang QL (2015) Impact of climate factors on $\mathrm{CO}_{2}$ flux characteristics in a Larix gmelinii forest ecosystem. Journal of Beijing Forestry University 37(8): 31-39

Tian Y, Zhang QL, Liu X, Meng M, Wang B (2019) The relationship between stem diameter shrinkage and tree bole moisture loss due to transpiration. Forests 10(03): 209

Flanagan LB, Comstock JP, Ehleringer JR (1991) Comparison of modeled and observed environmental influences on the stable oxygen and hydrogen isotope composition of leaf water in Phaseolus Vulgaris L. Plant Physiology 96(2): 588-596

Wang XF, Yakir D (2000) Using stable isotopes of water in evapotranspiration studies. Hydrological Processes 14(8): $1407-1421$

Williams DG, Cable W, Hultine K, Hoedjes JCB, Yepez EA, Simonneaux V, Er-Raki S, Boulet G, de Bruin HAR, Chehbouni A, Hartogensis OK, Timouk F (2004) Evapotranspiration components determined by stable isotope, sap flow and eddy covariance techniques. Agricultural and Forest Meteorology 125(3/4): $241-258$

Griffis TJ, Lee X, Baker JM, Sargent SD, King JY (2005) Feasibility of quantifying ecosystem-atmosphere $\mathrm{C}^{18} \mathrm{O}^{16} \mathrm{O}$ exchange using laser spectroscopy and the flux - gradient method. Agricultural and Forest Meteorology 135(1/4): 44-60

Gazis C, Feng X (2004) A stable isotope study of soil water: Evidence for mixing and preferential flow paths. Geoderma 119: $97-111$ 
Phillips DL, Newsome SD, Gregg JW (2005) Combining sources in stable isotope mixing models: Alternative methods. Oecologia 144: 520-527

Yakir D, Sternberg LDSL (2000) The use of stable isotopes to study ecosystem gas exchang. Oecologia 123(3): $297-311$

Cappa CD, Hendricks MB, DePaolo DJ, Cohen RC (2003) Isotopic fractionation of water during evaporation. Journal of Geophysical Research: Atmospheres doi: 1029/2003JD003597

Welp LR, Lee XH, Kim K, Griffis TJ, Billmark K A, Baker J M (2008) $\delta^{18} \mathrm{O}$ of water vapour, evapotranspiration and the sites of leaf water evaporation in a soybean canopy. Plant Cell and Environment 31(9): $1214-1228$

Komatsu H, Tanaka N, Kume T (2007) Do coniferous forests evaporate more water than broad—leaved forests in Japan. Journal of Hydrology 336: 361-375

Oishi AC, Oren R, Paul CS (2008) Estimating components of forest evapotranspiration: A footprint approach for scaling sap flux measurements. Agricultural and Forest Meteorology 148: 1719—1732

Lai CT, Ehleringer JR, Bond BJ, Paw UKY (2006) Contributions of evaporation, isotopic non - steady state transpiration and atmospheric mixing on the $\delta^{18} \mathrm{O}$ of water vapour in Pacific Northwest coniferous forests. Plant, Cell and Environment 29(1): 77—94

Zhu ZX, Xiao W, Zhang M, Wang W, Shen J, Xu JP, Hu YB, Wen XF, Li XH (2017) Hydrogen and oxygen isotopic composition of temperate deciduous forest ecosystem in Canada. Acta Ecologica Sinica 37 (22): $7539-7551$

Farquhar GD, Cernusak LA (2005) On the isotopic composition of leaf water in the non-steady state. Functional Plant Biology 32(4): 293-303

Flanagan LB, Ehleringer JR (1991) Stable isotope composition of stem and leaf water: application to the study of plant water use. Functional Ecology 5(2): 270-277

Yepez EA, Huxman TE, Ignace DD, English NB, Weltzind JF, Castellanose AE, Williams DG (2005) Dynamics of transpiration and evaporation following a moisture pulse in semiarid grassland: A chamberbased isotope method for partitioning flux components. Agricultural and Forest Meteorology 132(3/4): 359 $-376$

Nickerson N, Risk D (2009) Keeling plots are non-linear in non-steady state diffusive environments. Geophysical Research Letters doi: 10. 1029/2008GL036945

Moreira MZ, Sternberg LDSL, Martinelli LA, Victoria RL, Barbosa EM, Bonates LM, Nepstad DC (1997) 
Contribution of transpiration to forest ambient vapour based on isotopic measurements. Global Change Biology 3(5): 439-450

Wang XF, Yakir D (1995) Temporal and spatial variations in the $\delta^{18} \mathrm{O}$ content of leaf water in different plant species. Plant, Cell and Environment 18(12): 1377-1385 


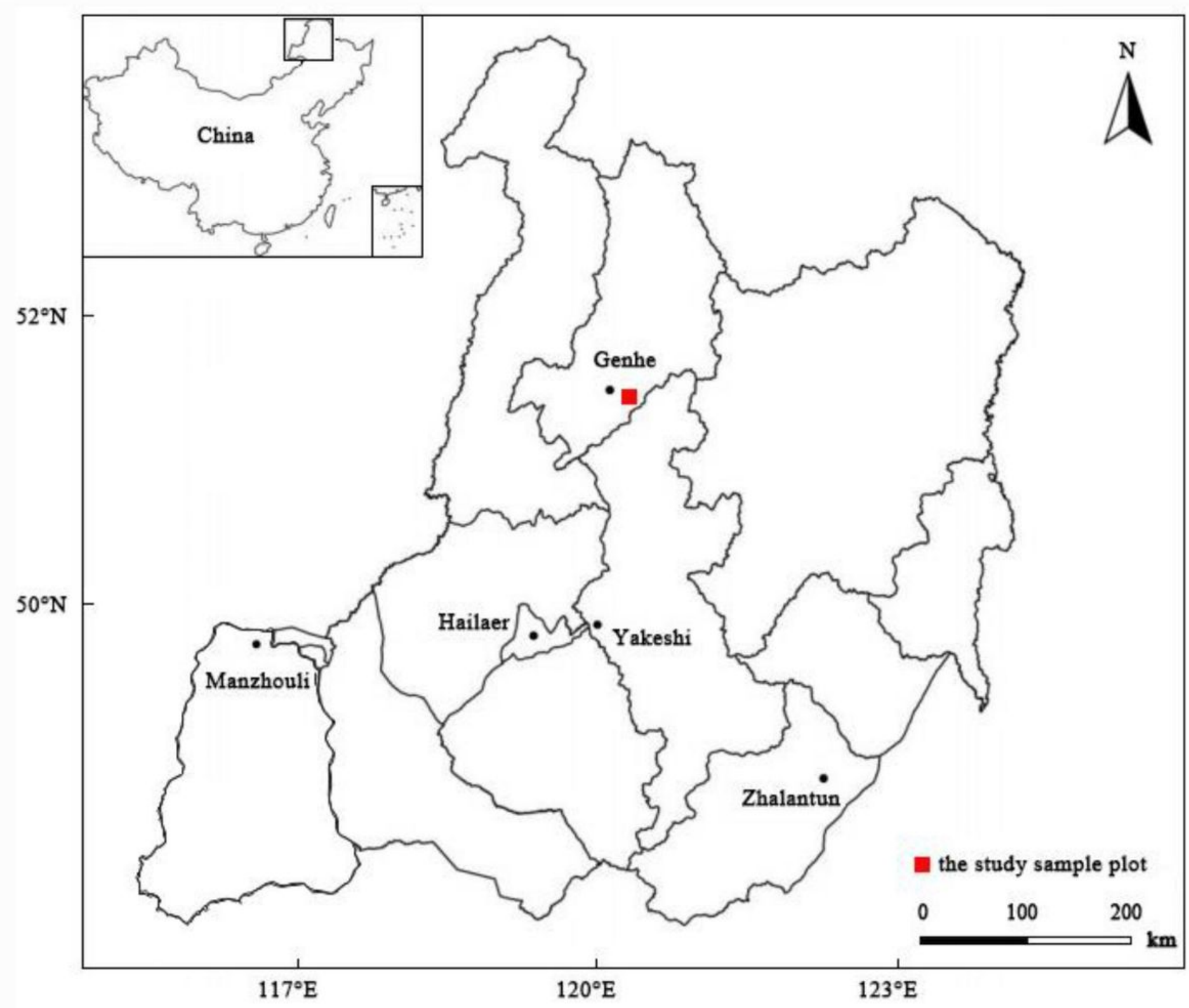

\section{Figure 1}

Location of the study area. Note: The designations employed and the presentation of the material on this map do not imply the expression of any opinion whatsoever on the part of Research Square concerning the legal status of any country, territory, city or area or of its authorities, or concerning the delimitation of its frontiers or boundaries. This map has been provided by the authors. 

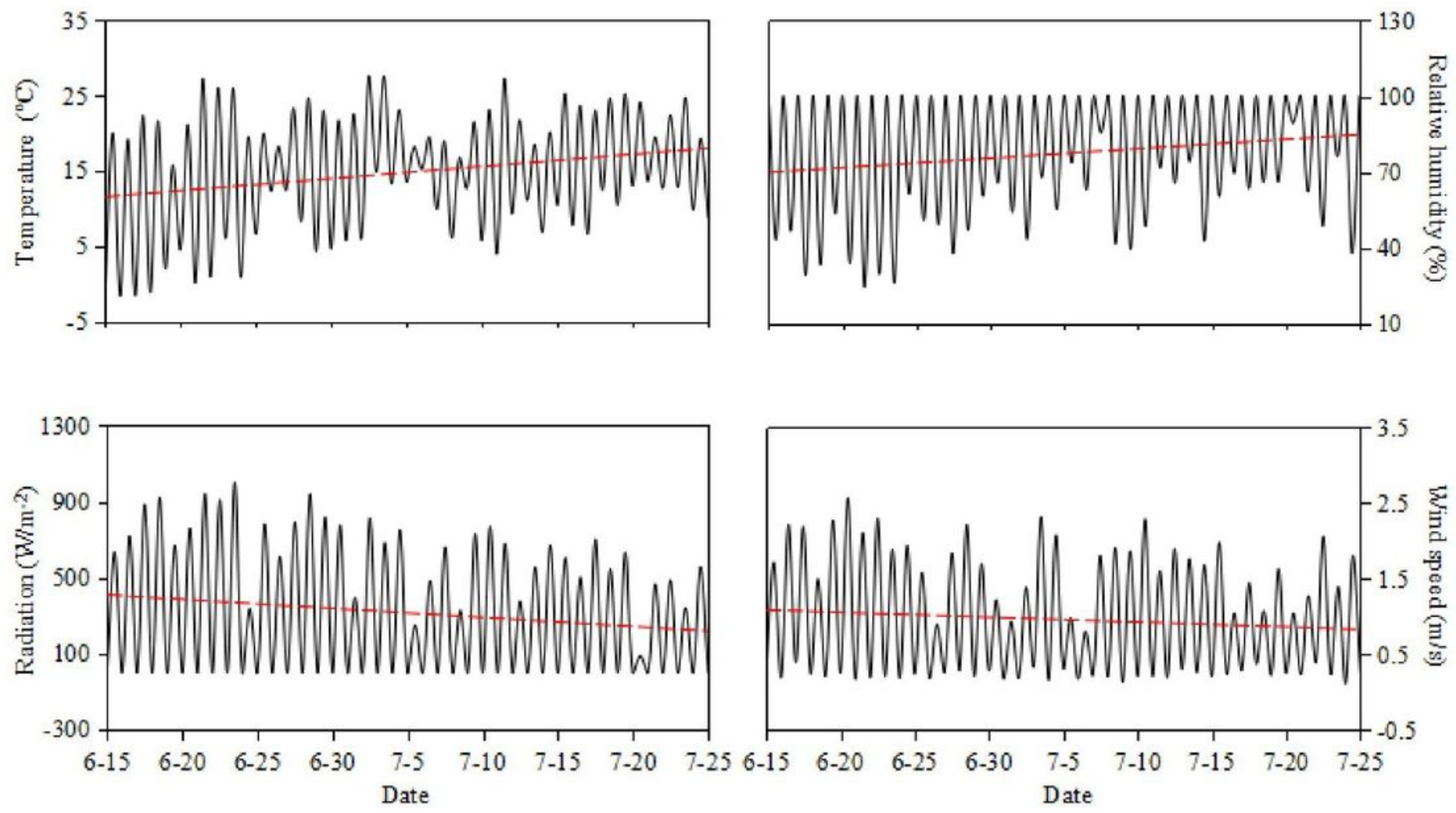

Figure 2

Changes in environmental factors during observation. 

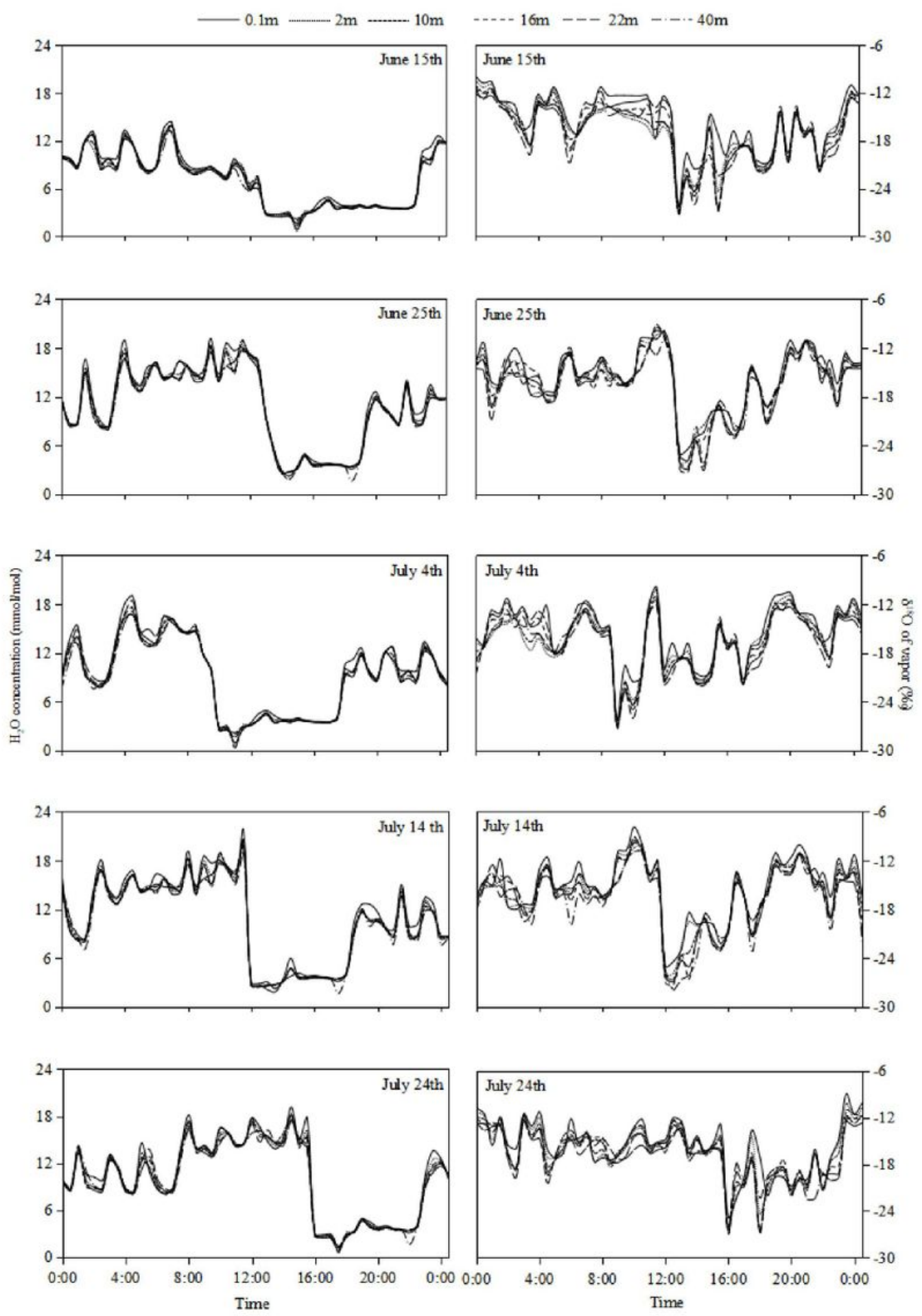

Figure 3

Diurnal variation of water vapor concentration (left) and $\delta 180$ (right) at different gradients of Larix gmelinii ecosystem. 

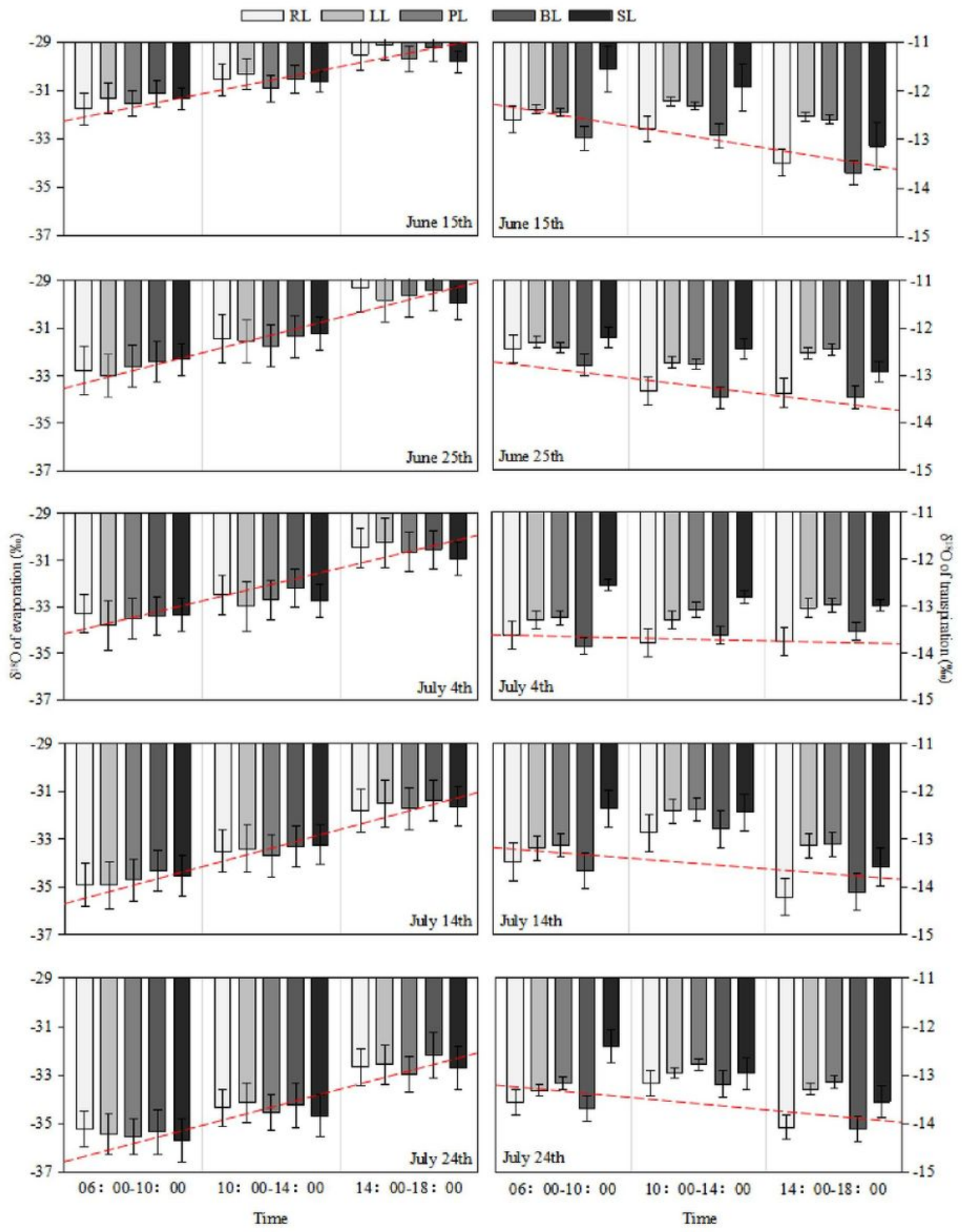

Figure 4

Changes of $\delta 180$ in soil evaporation (left) and plant transpiration (right) of different forest types. 

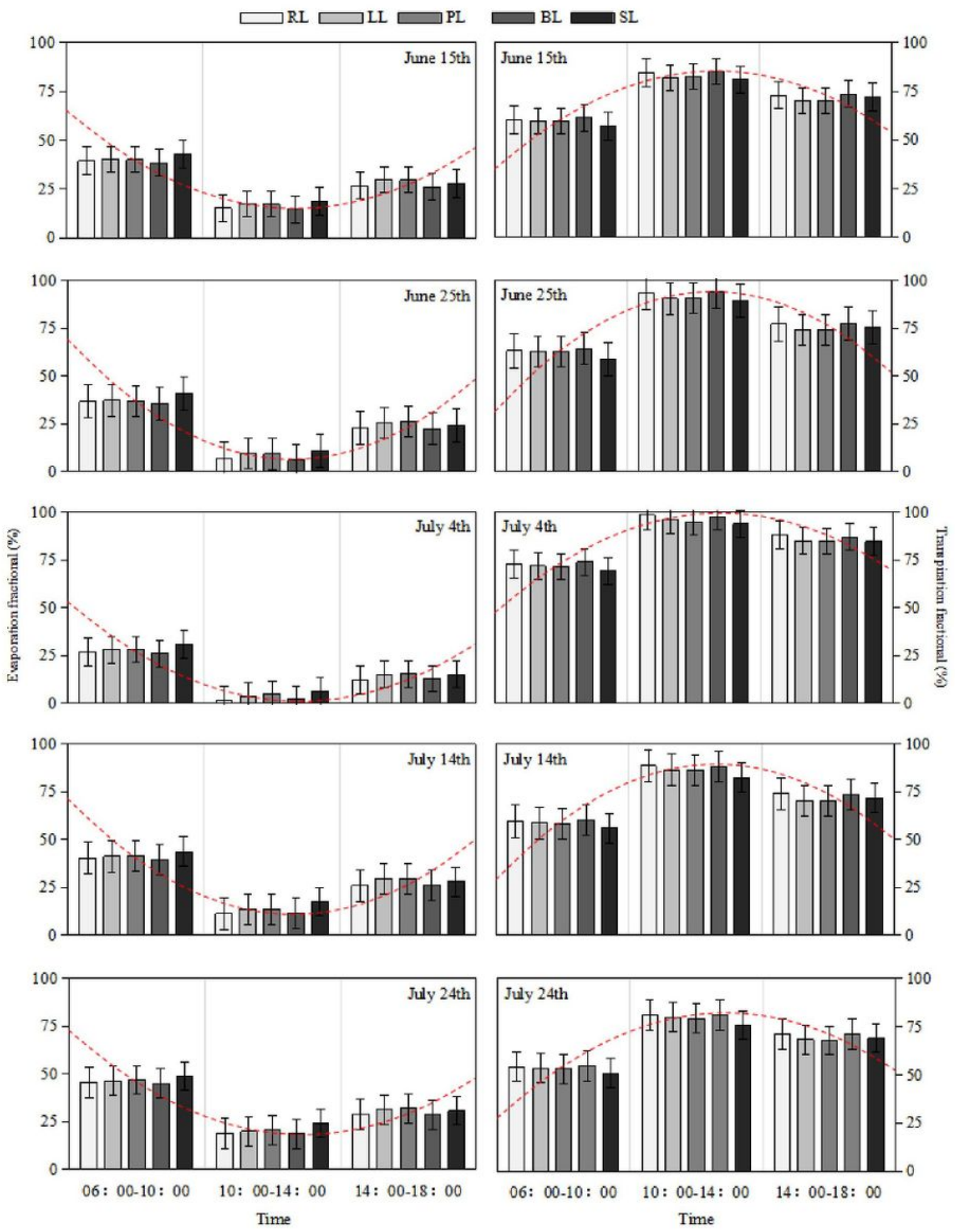

\section{Figure 5}

Proportion of soil evaporation (left)/plant transpiration (right) to ecosystem evapotranspiration in different forest types. 